Original Contribution

\title{
INFLUENCE OF THE CEREAL COMPONENTS REPLACEMENT WITH EXTRUDED BREAD WASTE IN THE LAYING HENS DIET ON THE NET UTILIZATION OF ENERGY AND PROTEIN
}

\author{
S. Grigorova ${ }^{1}$, D. Penkov ${ }^{2 *}$ \\ ${ }^{1}$ Institute of Animal Science - Kostinbrod, Bulgaria \\ ${ }^{2}$ Agricultural University, Plovdiv, Bulgaria
}

\begin{abstract}
Aim: Monitoring the effect of the replacement of 5 and $10 \%$ of the grain component in compound feed for laying hens with the same amount of extruded bread waste on Clarcs of energy distribution (CED)/ protein transformation (CPT)" in the eco-technical chain "fodder - egg mélange".

Experimental design: Three groups: 50 layers each (hybrid Lohman Klassic Brown), one - control, one - replacement of $5 \%$ of the grain, one - replacement of $10 \%$ of the grain with extruded bread waste.

Results: CED "ME fodder - GE mélange": control $-0.2064 ; 5 \%$ bread wastes $-0.2049 ; 10 \%$ bread wastes -0.2166 .

CPT "CP fodder - CP mélange": control $-0.2538 ; 5 \%$ bread wastes $-0.2585 ; 10 \%$ bread waste -0.2838 . There is a tendency for higher net utilization of energy and protein from feed to the egg mélange in the group receiving $10 \%$ bread wastes.
\end{abstract}

Key words: bread wastes, Clarc of energy distribution, Clarc of protein transformation, layers

\section{INTRODUCTION}

Food Waste (both precooked and leftover) is a biodegradable waste discharged from various sources: food processing industries; households; hospitality sector (1). FAO reported that nearly 1.3 billion tonnes of food including fresh vegetables, fruits, meat, bakery, and dairy products are lost along the food supply chain (2). Food waste has a high nutritional value. Thrown out to the environment, it causes ecological pollution (3, 4). Bread and others paste after expiration date can be used after extrusion in compound feed for non-ruminants and poultry $(5,6)$. Except to the beneficial ecological effects of their using, the bread waste inclusion in compound feeds for non-ruminants and poultry will save grain components $(7,8)$.

The net utilization of energy and protein in the chain "feed-food" has been objective of scientific interest in the recent years. In this

\footnotetext{
*Correspondence to: Dimo Penkov, Agricultural University - 4000 Plovdiv, 12 D. Mendeleev Str., Bulgaria, Email: dimopenkov@gmail.com
}

regard, the feed conversion ratio as a main indicator of nutrient's utilization in poultry no longer meets modern requirements (9-11). Penkov and Genchev (9) suggested the introduction of objective criteria Clarc of energy distribution (CED) and Clarc of protein/amino acids transformation (CPT), and Penkov and Grigorova (12) adapted the calculation of these indicators for laying poultry.

The aim of the current study is to investigate the effect of cereal component replacement (5\% and $10 \%$ ) in the compound feed of laying hens with extruded bread waste on Clarcs of energy distribution/protein transformation in the ecotechnical chain "fodder - egg mélange".

\section{MATERIAL AND METHODS}

An experiment was conducted in the period February-April 2020 at the Poultry Experimental Center of Institute of Animal Science-Kostinbrod with a total of 150 laying hens (35 weeks old) from Lohman Klassik Brown hybrid At the beginning of the experiment the poultry were randomly distributed into three groups (control and two 
experimental groups) in separate boxes, 50 layers each. The hens were housed on a deep litter pen on a $16 \mathrm{~h}$ lighting schedule. The compound feed of the control group had following composition: maize; soybean meal; sunflower meal; sunflower oil; limestone; monocalcium phosphate; salt; L lysine; mineral premix and vitamin premix. A part of the grain component in the feed of the experimental groups was replaced with 5\% (I experimental group) and $10 \%$ (II experimental group) extruded bread waste. The diets of all groups had the same nutritional value:11.31 MJ metabolizable energy; $18 \%$ crude protein; $4.5 \%$ crude fats; $4 \%$ crude fiber; $12.14 \%$ crude ash; $3.55 \% \mathrm{Ca} ; 0.54 \% \mathrm{P}$. All the groups received $130 \mathrm{~g}$ feed/day/hen. The duration of the experiment was 60 days.

The laying capacity (\%), the health status of the birds, the feed provided and the fodder rests were monitored daily. At the beginning and end of the experimental period, the following measurements were made on 30 eggs per group: masses of egg, egg yolk, egg white and shell with the sub-shell (with an electronic scale with an accuracy of $\pm 0.01 \mathrm{~g}$ ). Chemical analysis of egg white and yolk was made on 6 eggs per group, with a mass close to the average.

The chemical composition of feed and eggs was determined by the Weende method (14). The
GRIGOROVA S.. et al. metabolic energy of the feed was established according to (15). The gross energy in egg melange was calculated according to the formula of (16). The Clarcs of energy distribution (CED) / protein transformation (CPT) were calculated by the original formula (13):

$\mathrm{CED}=$ Consumed ME from 1 layer/produced GE through the egg white/yolk/mélange

$\mathrm{CPT}=$ Consumed $\mathrm{CP}$ from 1 layer/produced $\mathrm{CP}$ through the egg white/yolk/mélange

\section{RESULTS AND DISSCUSSION}

The indexes of the entrance of the eco technical system are shown in Table 1. The average daily fodder consumption ranged between 126 and 128 grams. The birds from the first experimental group have consumed lowest feed, followed by the control, and the highest consummation has been observed by the birds from the group with $10 \%$ bread waste. On this basis, the amounts of metabolizable energy received in the body of one layer $-86.673 \mathrm{MJ}$ (control), 86.619 MJ (I experimental) and 86.895 MJ (II experimental group) and crude protein - respectively $1.355,1.354$ and $1.375 \mathrm{~kg}$, were calculated. The differences in the feed amounts received are not significant $(\mathrm{P}>0.05)$ for both energy and protein.

Table 1. Consumed amounts of feed, metabolizable energy and crude protein on average from the laying hen for the whole experiment (entrance of the system)

\begin{tabular}{lccc}
\hline \multicolumn{1}{c}{ Groups } & Control group & $\begin{array}{c}\text { I-st exper.with } \\
5 \% \text { bread wastes }\end{array}$ & $\begin{array}{c}\text { 2-nd exper.with } \\
10 \% \text { bread wastes }\end{array}$ \\
\hline Consumed feed $-\mathrm{kg}$ & $7.575 \pm 0.22$ & $7.570 \pm 0.28$ & $7.683 \pm 0.25$ \\
Consumed metabolizable energy- MJ & $86.673 \pm 2.48$ & $85.619 \pm 3.17$ & $86.895 \pm 2.82$ \\
Consumed crude protein $-\mathrm{kg}$ & $1.355 \pm 0.039$ & $1.354 \pm 0.036$ & $1.375 \pm 0.038$ \\
\hline
\end{tabular}

Chemical composition of egg albumen and egg yolk of the hens from all the groups is shown in Table 2. Significant higher protein content in the egg yolk $(\mathrm{P}<0.05)$ and egg albumen $(\mathrm{P}<0.05)$ in the layers from II experimental group in comparison with the control and I experimental group was established. These results may be explained with the higher protein digestibility of compound feed with $10 \%$ extruded bread waste. Using methods for balance experiments, (17) determined the coefficient of true digestibility of protein $(\mathrm{CTDP}=84.15)$ and apparent metabolizable energy - zero corrected $($ Men-o $)=14.17 \mathrm{MJ} / \mathrm{kg}$
DM in bread wastes from Bulgarian bakery industry.

There is not significant difference $(\mathrm{P}>0.05)$ of albumen and yolk chemical composition between control and I experimental group.

The accumulated gross energy per unit protein and yolk was also significantly higher $(\mathrm{P}<0.05)$ in the eggs of the second experimental group compared to the control, but between the two experimental groups, the differences are not significant. 
GRIGOROVA S.. et al.

Table 2. Chemical composition and metabolizable energy (ME) in egg albumen and egg yolk of hens from control and experimental groups

\begin{tabular}{lccc}
\hline \multicolumn{1}{c}{ Groups } & Control group & $\begin{array}{c}\text { With 5\% bread } \\
\text { wastes }\end{array}$ & $\begin{array}{c}\text { With 10\% bread } \\
\text { wastes }\end{array}$ \\
\hline & Egg white & & \\
Crude protein (CP) \% & $10.95 \pm 0.28^{*}$ & $11.05 \pm 0.37 \mathrm{a}$ & $12.50 \pm 0.41^{*} \mathrm{a}$ \\
Crude fats, \% & $0.54 \pm 0.02$ & $0.40 \pm 0.01$ & $0.30 \pm 0.01$ \\
NPE \% & $0.50 \pm 0.02$ & $0.20 \pm 0.01$ & $0.42 \pm 0.02$ \\
Gross energy (GE), MJ/kg & $5.87 \pm 0.08^{*}$ & $5.60 \pm 0.08 \mathrm{a}$ & $6.34 \pm 0.12 * \mathrm{a}$ \\
& Egg yolk & & \\
Crude protein (CP)\% & $16.23 \pm 0.35^{*}$ & $17.07 \pm 0.48$ & $17.48 \pm 0.37 *$ \\
Crude fats, \% & $30.26 \pm 0.47$ & $30.95 \pm 0.23$ & $31.07 \pm 0.57$ \\
NPE \% & $0.25 \pm 0.01$ & 0.00 & 0.00 \\
ME - MJ/kg & $15.05 \pm 0.25^{*}$ & $15.46 \pm 0.32$ & $15.93 \pm 0.45^{*}$ \\
\hline N &
\end{tabular}

Notice: *-*Significant between control and experimental groups by $\mathrm{P} \leq 0.05$ a-a Significant between the experimental groups by $\mathrm{P} \leq 0.05$

The accumulated amounts of gross energy and crude protein in the produced proteins and yolks on average from one layer for the whole experiment in all the groups and the Clarcs of energy distribution / protein transformation are presented in Table 3.

For both yolks and albumens, despite not significantly differences, there is a trend, the group receiving feed with $10 \%$ bread wastes to produce more crude protein and gross energy compared to both the control and the group with $5 \%$ bread waste. This trend is mainly due to a significantly $(\mathrm{P}<0.05)$ higher content of crude protein in the edible parts of the eggs. Due to the fact that the hens in this group consumed (although insignificant) more feed (respectively metabolizable nergy and crude protein), the differences in the indexes reflecting the biotransformation along the chain "feed - egg mélange" are statistically insignificant $(\mathrm{P}>$ $0.05)$.

Table 3. Produced gross energy $(G E)$ and crude protein $(C P)$ from one layer for the whole experimental period and Clarcs of energy distribution (CED)/ protein transformation (CPT)

\begin{tabular}{lccc}
\hline \multicolumn{1}{c}{ Groups } & Control group & $\begin{array}{c}\text { With 5\% bread } \\
\text { wastes }\end{array}$ & $\begin{array}{c}\text { With 10\% bread } \\
\text { wastes }\end{array}$ \\
\hline Produced CP with the egg white - kg & $0.22 \pm 0.01$ & $0.22 \pm 0.01$ & $0.25 \pm 0.02$ \\
Produced CP with the egg yolk - kg & $0.13 \pm 0.01$ & $0.13 \pm 0.01$ & $0.14 \pm 0.01$ \\
Produced GE with the egg white - MJ & $5.87 \pm 0.08$ & $5.60 \pm 0.08$ & $6.34 \pm 0.12$ \\
Produced GE with the egg yolk - MJ & $12.02 \pm 0.21$ & $11.94 \pm 0.19$ & $12.48 \pm 0.39$ \\
Clarc of energy distribution „ME & $0.0677 \pm 0.008$ & $0.0654 \pm 0.006$ & $0.0730 \pm 0.008$ \\
fodder-GE white“ & $(6.77 \%)$ & $(6.54 \%)$ & $(7.30)$ \\
Clarc of energy distribution „ME & $0.1387 \pm 0.011$ & $0.1395 \pm 0.010$ & $0.1436 \pm 0.015$ \\
fodder-GE yolk“ & $(13.87 \%)$ & $(13.95 \%)$ & $(14.36 \%)$ \\
Clarc of energy distribution „ME & $0.2064 \pm 0.01$ & $0.2049 \pm 0.009$ & $0.2166 \pm 0.011$ \\
fodder-GE mélange“ & $(20.64 \%)$ & $(20.49 \%)$ & $(21.66 \%)$ \\
Clarc of protein transformation „CP & $0.1624 \pm 0.01$ & $0.1625 \pm 0.01$ & $0.1819 \pm 0.01$ \\
fodder-CP white“ & $(16.24 \%)$ & $(16.25 \%)$ & $(18.19 \%)$ \\
Clarc of protein transformation „CP & $0.0959 \pm 0.01$ & $0.0960 \pm 0.01$ & $0.1019 \pm 0.01$ \\
fodder-CP yolk“ & $(9.59 \%)$ & $(9.60 \%)$ & $(10.19 \%)$ \\
Clarc of protein transformation „CP & $0.2583 \pm 0.01$ & $0.2585 \pm 0.01$ & $0.2838 \pm 0.01$ \\
fodder-CP mélange“ & $(25.83 \%)$ & $(25.85 \%)$ & $(28.38 \%)$ \\
\hline
\end{tabular}

However, the trend of higher net utilization (higher Clarcs) of energy and protein in the group with included $10 \%$ bread waste compared to the other two groups is of interest for further research. The calculated CED and CPT in the present study are compatible with those obtained by us in experiments with the same hybrid (13), but with different aims and experimental design. 


\section{CONCLUSIONS}

The following values for the net utilization of the energy and the protein have been observed:

-For the Clarc of energy distribution (CED):

-fodder - egg white: control group - 0.0677; 5\%

bread wastes $-0.0654 ; 10 \%$ bread wastes -0.0730

- fodder - egg yolk: control group - $0.1387 ; 5 \%$

bread wastes $-0.1395 ; 10 \%$ bread wastes -0.1436

-fodder - egg mélange: control group - 0.2064;

$5 \%$ bread wastes $-0.2049 ; 10 \%$ bread wastes 0.2166 .

-For the Clarc of protein transformation (CPT):

-fodder - egg white: control group - 0.1624; $5 \%$

bread wastes $-0.1625 ; 10 \%$ bread wastes -0.1819

-fodder - egg yolk: control group - 0.0959; 5\%

bread wastes $-0.0960 ; 10 \%$ bread wastes -0.1019

-fodder - egg mélange: control group - 0.2583;

$5 \%$ bread wastes $-0.2585 ; 10 \%$ bread wastes 0.2838 .

There is a tendency for higher net utilization of energy and protein from feed to the egg mélange in the group receiving $10 \%$ bread wastes.

\section{REFERENCES}

1. Paritosh, K.,Kyshwaha, S.K.,Yadav, M., Pareek, N., Chawade, A., Vivekanand, V. Food waste to energy: An overview of sustainable approaches for food waste management and nutrient recycling. BioMed Research International, 2017(2):1-19, 2017

2. FAO, Towards the Future we Want: End Hunger and Make the Transition to Sustainable Agricultural and Food Systems, Food and Agriculture Organization of the United Nations, Rome, 2012.

3. Chung, JC., Strategy for active recycling of food waste. Journal of Korea Solid Wastes Engineering Society, 18(8), 22-29, 2001.

4. Food and Agriculture Organization of the United Nations - FAO, Global Food Losses and Food Waste - Extent, Causes and Prevention; Food and Agriculture Organization of the United Nations: Rome, Italy, 2011.

5.Yadav, D.S., Shrivastava, M., Singh, J.P.,Mishra, A.K., Effect of replacement of maize with bakery waste in broiler ration. International Journal of Agricultural Sciences and Veterinary Medicine, 2(1), 2833, 2014.

6. Krička, T., Janječi, Z., Bilandzija, N., Bedekovic, D., Voca, N.,Matin, A., Jurisic, V., Crubor, M., Nutritional usability of thermal treated white and brown bread in broiler feed. Journal of Central European Agriculture, 20(3), 788-795., 2019.
GRIGOROVA S.. et al.

7. US-EPA, Advancing sustainable materials management: 2014 fact sheet: assessing trends in material generation, recycling, com-posting, combustion with energy recovery and landfilling in the United States. Protection Agency, Office of Land and Emergency Management (5306P), EPA530-R-17-01. Washington, DC, USA, 2016.

8. Al.Tulaihan, A.A., Najib, H., Al-Eid, S.M., The nutritional evaluation of locally produced dried bakery waste (DBW) in the broiler diets. Pakistan Journal of Nutrition, 3(5), 294-299, 2004.

9. Kabakchiev, M., Alexieva, D., Genchev, A., Nikolova M., Gerzilov, V., Poultry Breeding, ISBN 9789545172076, pp 488, 2014 (in Bulgarian).

10. Lukanov H, Petrov .,P, Genchev A, Halil E, Ismail Nлр Productive performance of Easter egger crosses of Araucana and Schijndelaar roosters with white Leghorn hens. Trakia Journal of Sciences, 1: 72 - 79, ISSN 13121723, 2016.

11.Nickolova, M. and Chatalbashev N., Investigation on egg productivity of ostriches (Struthio camelus).1 Laying capacity, Agricultural Sciences, 2(3), 63-69, 2010.

12. Penkov, D. and Genchev, A., Methods for introduction of objective criteria for bioconversion of energy and nutrients along the feed - animal products chain in meet-type poultry farming. Journal of Central European Agriculture, 19 (2) 270-277, 2018.

13.Penkov, D. and S. Grigorova, S., Methodology for reporting of the energy and protein transformation in the eco-technical chain "feed-egg mélange"by laying hens through introducing of "Clarc of energy distribution/Clarc of protein transformation", Trakia Journal of Sciences, 1, 20-24, 2020.

14.AOAC international, Official methods of analysis of AOAC (18 edition, rev. 2), Association of Official Analytical Chemists Intern., Gaithersburg, MD, USA, 2007.

15.Marinov, B., Nutrition of laying hens. Ifo Dizain, Provimi, Sofia, Bulgaria, 2004.

16.Schiemann, R., K. Niering, L. Hoffmann, W. Jench, and A. Chudy, Energetische Fuetterung und Energienormen. VEB Deutscher Landwirtschaftsverlag, Berlin, 1971.

17.Penkov, D. and Chobanova, S., Metabolizable energy and true digestibility of the proteinof extruded of bakery by-products (bread wastes) in balanced experiments with poultry. Journal of Central European Agriculture, 21(3), 517521,2020 